\title{
In vitro anti-diabetic activity of stingless bee honey from different botanical origins
}

\author{
Ali, H., *Abu Bakar, M.F., Majid, M., Muhammad, N. and Lim, S.Y. \\ Faculty of Applied Sciences and Technology, Universiti Tun Hussein Onn Malaysia (UTHM), Pagoh \\ Educational Hub, 84600 Pagoh, Johor, Malaysia
}

\begin{abstract}
Article history:
Received: 11 December 2019

Received in revised form: 10

March 2020

Accepted: 12 March 2020

Available Online: 7 April 2020
\end{abstract}

Keywords:

Stingless bee honey,

Phenolic,

Flavonoid,

$\alpha$-amylase inhibition,

$\alpha$-glucosidase inhibition

DOI:

https://doi.org/10.26656/fr.2017.4(5).411

\begin{abstract}
The number of patients with diabetes mellitus is increasing at an alarming rate and this situation has triggered the interest of searching natural product as an alternative treatment. Stingless bee honey containing a diverse array of bioactive compounds is commonly utilized as a functional food and also found to possess various therapeutic effects including anti-diabetic through $\alpha$-amylase and $\alpha$-glucosidase inhibition. However, the composition level of bioactive compounds varying of geographical origins and botanical sources of honey leads to different enzyme inhibition abilities. Therefore, this study explored the total phenolic, total flavonoid, $\alpha$-amylase and $\alpha$-glucosidase inhibition activities of stingless bee honey from various botanical origins. In this study, stingless bee honey was collected from 6 different botanical origins namely, acacia, coconut, mangrove, starfruit, multifruit and multiflower plant. Honey from tualang tree was used as a positive control. Phenolic and flavonoid contents as well as $\alpha$-amylase and $\alpha$-glucosidase inhibition activities of honey were studied spectrophotometrically. Stingless bee honey from mangrove was found to have the highest phenolic content (141.74 $\pm 0.03 \mathrm{mg} \mathrm{GAE} / 100 \mathrm{~g}$ ). The honey collected from coconut origin showed the highest flavonoid content with the value of $51.33 \pm 0.02 \mathrm{mg} \mathrm{RE} / 100 \mathrm{~g}$ and also achieved the highest percentage inhibition against $\alpha$-glucosidase $(68.33 \%$ at $100 \mu \mathrm{g} / \mathrm{mL})$. Furthermore, tualang honey and honey samples from mangrove, coconut and Acacia tree were found to have strong $\alpha$-amylase inhibition abilities as their inhibition percentages were more than $70.00 \%$ at $100 \mu \mathrm{g} / \mathrm{mL}$. This study showed that the presence of flavonoid and phenolic compounds in honey from different botanical origins yielded different degree of $\alpha$-amylase and $\alpha$-glucosidase inhibition and also recommended the uses of stingless bee honey in diabetes treatment.
\end{abstract}

\section{Introduction}

Diabetes mellitus is one of metabolic diseases characterized by chronic hyperglycemia that triggers the carbohydrate, fat and protein metabolism disorders in the human body, leading to long-term damage and dysfunction of various organs (Alberti and Zimmet, 1998; Rahmawati et al., 2019). In 2017, approximately 451 million of the population were affected by this disease and it had brought up to 5 million deaths in the worldwide population in the same year (Rutebemberwa et al., 2013). In addition, the number of patients is predicted to increase by years up to 693 million in 2045 (Cho et al., 2018). Failure in recognizing diabetes treatment as priority became the major factor that leads to morbidity and even increases the rate of mortality globally (Shaw et al., 2010). However, the high cost of disease treatment has led to a financial burden to patients with diabetes, especially those in developing countries. Therefore, there is an urge to encourage people to search for an alternative way such as lifestyle modification including a change of dietary intake to enhance the treatment of patients suffering from diabetes.

Honey, a sugary secretion extracted from honeycombs comprises more than 200 constituents including the main substances such as fructose and glucose (Eteraf-Oskouei and Najafi, 2013). It is known as one of the natural products that have potential health benefits to human and among a variety of honey, stingless bee honey is considered as one of the food substances that used for natural remedies. Basically, it is produced by the stingless bees from the family of Meliponini, which made up of various types of genera such as Melipona, Trigona, and Heterotrigona whereas among the stingless bee species, Geniotrigona thoracica, 
Heterotrigona itama, Lepidotrigona terminata and also Tetragonula laeviceps are reared commercially in Malaysia (Mohd Rafie et al., 2018). Stingless bee honey has been reported to contain rich phytochemical contents and possess anti-inflammatory, antimicrobial, antioxidant, anticancer and antiseptic properties as well as to boost the immune system (Eteraf-Oskouei and Najafi, 2013; Abd Jalil et al., 2017; Akhir et al., 2017). Furthermore, it displays specific anti-diabetic role in the inhibition of $\alpha$-amylase and $\alpha$-glycosidase enzyme activity by controlling the glucose content in the human body (Campone et al., 2014).

However, the nutritional content, physiochemical properties and variety of bioactive compounds of honey might be affected by several factors such as geographical origins, their botanical sources and environmental factor (Majid et al., 2019; Lim et al., 2019). Thus, this study was aimed to determine phenolic and flavonoid contents as well as to evaluate the $\alpha$-amylase and $\alpha$-glucosidase inhibition activities of honey collected from the stingless bee, Heterotrigona itama in different botanical origins.

\section{Materials and methods}

\subsection{Sample preparation}

The sample chosen in this study was stingless bee honey from $H$. itama $\mathrm{sp}$. The stingless bee honey samples were collected from six botanical origins including Acacia tree, mangrove tree, coconut tree, multiflower plant, multifruit plant and starfruit tree while honey from tualang tree was used as a positive control. Then, the honey samples were stored at $4^{\circ} \mathrm{C}$ for further analysis.

\subsection{Determination of total phenolic content}

Folin-Ciocalteu method was conducted to determine the total phenolic content of honey samples (Yap et al., 2015; Istasse et al., 2016). The absorbance was measured spectrophotometrically at $725 \mathrm{~nm}$. A calibration curve (y $\left.=0.009 \mathrm{x}-0.0217 ; \mathrm{R}^{2}=0.9914\right)$ was used to calculate the total phenolic content. The experiment was carried out in triplicate and the results were expressed as $\mathrm{mg}$ of Gallic acid equivalent (GAE) per $100 \mathrm{~g}$ of honey.

\subsection{Determination of total flavonoid content}

Total flavonoid content was determined based on the method as stated in the study of Islam et al. (2017) with some modification. The absorbance was measured spectrophotometrically at $510 \mathrm{~nm}$. A calibration curve (y $\left.=0.0021 \mathrm{x}+0.004 ; \mathrm{R}^{2}=0.9869\right)$ was used to calculate the total flavonoid content and the result was expressed as mg of Rutin equivalents (RE) per $100 \mathrm{~g}$ of honey.

\subsection{Determination of $\alpha$-amylase inhibition assay}

$\alpha$-amylase inhibition activity was carried out based on the method of Inoue et al. (2007) with some modification. The reaction mixture containing $500 \mu \mathrm{L}$ of appropriate dilutions $(20-100 \mu \mathrm{g} / \mathrm{mL})$ of the honey sample, $500 \mu \mathrm{L}$ of $0.02 \mathrm{M}$ sodium phosphate buffer $(\mathrm{pH}$ $6.9)$ and porcine pancreatic $\alpha$-amylase $(0.5 \mathrm{mg} / \mathrm{mL})$ was incubated at $25^{\circ} \mathrm{C}$ for 10 mins. Then, $500 \mu \mathrm{L}$ of $1 \%$ starch solution in $0.02 \mathrm{M}$ sodium phosphate buffer was added to the mixture and the mixture was incubated at $25^{\circ} \mathrm{C}$ for another 10 mins. After incubation, dinitro salicylic acid (DNSA) solution was added to the mixture. The reaction was stopped by incubating the mixture in boiling water bath for 5 mins and then left to cool at room temperature. A total of $10 \mathrm{~mL}$ of distilled water was added to dilute the reaction mixture. The absorbance was measured spectrophotometrically at $540 \mathrm{~nm}$. The reference sample was tested in the same way with the exception of the test sample and the result was expressed as percentage inhibition.

\subsection{Determination of $\alpha$-glycosidase inhibition assay}

$\alpha$-glucosidase inhibitory activity was conducted according to the study of Apostolidis et al. (2007) with some modification. $100 \mu \mathrm{L}$ of $\alpha$-glucosidase $(0.5 \mathrm{mg} /$ $\mathrm{mL}$ ) in $0.1 \mathrm{M}$ phosphate buffer ( $\mathrm{pH} 6.0$ ) solution was added to $150 \mu \mathrm{L}$ of appropriate dilutions $(20-100 \mu \mathrm{g} / \mathrm{mL})$ of extracts and incubated at $25^{\circ} \mathrm{C}$ for 10 mins. Then, the mixture was incubated at $25^{\circ} \mathrm{C}$ for another 5 mins after the addition of $100 \mu \mathrm{L}$ of $5 \mathrm{mM}$ p-nitrophenyl- $\alpha-\mathrm{D}-$ glucopyranoside in $0.1 \mathrm{M}$ phosphate buffer ( $\mathrm{pH}$ 6.9) solution. After incubation, the absorbance was measured spectrophotometrically at $405 \mathrm{~nm}$. The reference sample was tested in the same way with the exception of the test sample and the result was expressed as percentage inhibition.

\subsection{Statistical analysis of the data}

$50 \%$ inhibition $\left(\mathrm{IC}_{50}\right)$ values of $\alpha$-amylase and $\alpha$ glucosidase activities were determined from the regression analysis. Correlation analysis was conducted to determine the relationship between the flavonoids, phenolic compounds and inhibition activities of $\alpha$ amylase and $\alpha$-glucosidase.

\section{Results and discussion}

\subsection{Total phenolic content}

Total phenolic content in this study was ranged from $77.52 \pm 0.02$ to $141.74 \pm 0.03$ (mg GAE/100 g) at the concentration of $100 \mu \mathrm{g} / \mathrm{mL}$ (Table 1). Stingless bee honey from mangrove origin showed the highest phenolic content with the value of $141.74 \pm 0.03$ (mg 
GAE/100 g); followed by the honey from coconut tree with the second highest phenolic content of $101.41 \pm 0.06$ (mg GAE/100 g). The descending trend of total phenolic content in honey samples from other botanical origins were shown as follow: Acacia (99.74 $\pm 0.08 \mathrm{mg} \mathrm{GAE} / 100$ g) > tualang $(89.19 \pm 0.01 \mathrm{mg}$ GAE $/ 100 \mathrm{~g})>$ starfruit $(85.74 \pm 0.02 \mathrm{mg} \mathrm{GAE} / 100 \mathrm{~g})>$ multiflower $(83.08 \pm 0.04$ mg GAE/100 g) > multifruit $(77.52 \pm 0.02 \mathrm{mg} \mathrm{GAE} / 100$ g). The composition of honey varies depending on the botanical origins and the result of this study was in agreement with the study of Shamsudin et al. (2019). In general, polyphenols in honey play an important role to maximize the efficiency of some biological activities that take place in the human body (Hoffman and Gerber, 2015). Therefore in this study, the presence of polyphenol compounds in honey might responsible for the $\alpha$-amylase and $\alpha$-glycosidase inhibition activity.

Table 1. Total phenolic content for honey samples

\begin{tabular}{cc}
\hline Samples & Phenolic content $(\mathrm{mg} \mathrm{GAE} / 100 \mathrm{~g})$ \\
\hline Acacia (K1) & $99.74 \pm 0.08$ \\
Coconut (K2) & $101.41 \pm 0.06$ \\
Mangrove (K3) & $141.74 \pm 0.03$ \\
Starfruit (K4) & $85.74 \pm 0.02$ \\
Multifruit (K5) & $77.52 \pm 0.02$ \\
Multiflower (K6) & $83.08 \pm 0.04$ \\
Tualang (K7) & $89.19 \pm 0.01$ \\
\hline
\end{tabular}

Honey samples were labelled as: K1 represents acacia tree; $\mathrm{K} 2$ represents coconut tree; $\mathrm{K} 3$ represents mangrove tree; K4 represents starfruit tree; K5 represents multifruit plant; K6 represents multiflower plant; K7 represents tualang tree. Each value was shown in mean \pm standard deviation $(n=3)$.

\subsection{Total flavonoid content}

Total flavonoid content values were ranged from $13.71 \pm 0.02$ to $51.33 \pm 0.02(\mathrm{mg} \mathrm{RE} / 100 \mathrm{~g}$ ) (Table 2). Stingless bee honey from coconut origin displayed the highest flavonoid content with the value of $51.33 \pm 0.02$ (mg RE/100 g) and the second highest flavonoid content value of $44.66 \pm 0.02(\mathrm{mg} \mathrm{RE} / 100 \mathrm{~g})$ was observed in the honey sample from the mangrove tree. Total flavonoid content of honey samples from other origins was arranged in the descending order as shown follow: multifruit $(41.33 \pm 0.01 \mathrm{mg} \mathrm{RE} / 100 \mathrm{~g})>$ starfruit $(32.28 \pm 0.04 \mathrm{mg} \mathrm{RE} / 100 \mathrm{~g})>$ Acacia $(29.42 \pm 0.01 \mathrm{mg}$ $\mathrm{RE} / 100 \mathrm{~g})>$ multiflower $(19.42 \pm 0.05 \mathrm{mg} \mathrm{RE} / 100 \mathrm{~g})>$ tualang $(13.71 \pm 0.02 \mathrm{mg} \mathrm{RE} / 100 \mathrm{~g})$. The overall result showed that the stingless bee honey samples were found to have more total flavonoid content than the tualang honey and this was analogue to the study of Abu Bakar et al. (2017) as the total flavonoid content of H. itama honey collected from different locations was much higher than tualang honey. The variation on the composition of flavonoid compounds in honey that observed in this study was likely due to the floral sources but geographical locations, seasonal and environmental factors could also be one of the reasons (Kaskoniene and Venskutonis, 2010). According to Erejuwa et al. (2011), elimination of excess free radicals from body might be one of the preventions among diabetic patients. Hence, the result in this study was in compliance with the statement as the presence of flavonoid in all the honey samples could act as a free radical scavenger.

Table 2. Total flavonoid content for honey samples

\begin{tabular}{cc}
\hline Samples & Flavonoid content $(\mathrm{mg} \mathrm{RE} / 100 \mathrm{~g})$ \\
\hline Acacia (K1) & $29.42 \pm 0.01$ \\
Coconut (K2) & $51.33 \pm 0.02$ \\
Mangrove (K3) & $44.66 \pm 0.02$ \\
Starfruit (K4) & $32.28 \pm 0.04$ \\
Multifruit (K5) & $41.33 \pm 0.01$ \\
Multiflower (K6) & $19.42 \pm 0.05$ \\
Tualang (K7) & $13.71 \pm 0.02$ \\
\hline
\end{tabular}

Honey samples were labelled as: K1 represents acacia tree; $\mathrm{K} 2$ represents coconut tree; $\mathrm{K} 3$ represents mangrove tree; K4 represents starfruit tree; K5 represents multifruit plant; K6 represents multiflower plant; K7 represents tualang tree. Each value was shown in mean \pm standard deviation $(n=3)$.

\section{$3.3 \alpha$-amylase inhibition assay}

All honey samples exhibited $\alpha$-amylase inhibition ability at the concentrations ranged from 20 to $100 \mu \mathrm{g} /$ $\mathrm{mL}$. Based on the result obtained in Table 3, the percentage of $\alpha$-amylase inhibition increased as the concentrations of honey samples increased. At a concentration of $100 \mu \mathrm{g} / \mathrm{mL}$, the highest activity was observed in the tualang honey $(74.83 \%)$, followed by the mangrove (72.15\%), coconut (71.65\%), Acacia (70.30\%), multifruit (55.76\%), multiflower (46.76\%) and starfruit $(36.78 \%)$. The percentages inhibition of $\alpha$ amylase at $80 \mu \mathrm{g} / \mathrm{mL}$ was recorded with the values from 27.03 to $59.57 \%$ while the percentage inhibition beyond $60 \mu \mathrm{g} / \mathrm{mL}$ was less than $50 \%$. Starfruit honey showed the least $\alpha$-amylase percentage inhibition $(0.17-36.77 \%)$ along the concentrations. $\mathrm{IC}_{50}$ values of the honey samples were ranged from 66.86 to $128.75 \mu \mathrm{g} / \mathrm{mL}$. Tualang honey achieved the highest inhibition activity with its low $\mathrm{IC}_{50}$ value and this could be related to the presence of more phenolic acid in the honey. Phenolic compounds that present in tualang honey such as kaempferol, caffeic acid and p-coumaric acid were found to have anti-diabetic properties and they might contribute to the $\alpha$-amylase inhibition activity (Ahmed and Othman, 2013; Bharti et al., 2017). However, stingless bee honey samples from mangrove, coconut and Acacia trees could also be a good $\alpha$-amylase inhibitor to reduce postprandial blood glucose levels in the body because their inhibition abilities were more than $70 \%$ at $100 \mu \mathrm{g} / \mathrm{mL}$. 
Table 3. $\alpha$-amylase inhibition of honey samples

\begin{tabular}{cccccc}
\hline \multirow{2}{*}{ Samples } & \multicolumn{5}{c}{ Inhibition activity (\%) } \\
\cline { 2 - 6 } & $20 \mu \mathrm{g} / \mathrm{mL}$ & $40 \mu \mathrm{g} / \mathrm{mL}$ & $60 \mu \mathrm{g} / \mathrm{mL}$ & $80 \mu \mathrm{g} / \mathrm{mL}$ & $100 \mu \mathrm{g} / \mathrm{mL}$ \\
\hline Acacia (K1) & 1.23 & 9.29 & 39.48 & 46.38 & 70.29 \\
Coconut (K2) & 0.41 & 13.6 & 28.39 & 45.64 & 71.65 \\
Mangrove (K3) & 21.24 & 33.2 & 45.15 & 56.74 & 72.14 \\
Starfruit (K4) & 0.17 & 7.44 & 19.02 & 27.03 & 36.77 \\
Multifruit (K5) & 6.82 & 20.13 & 26.54 & 50.45 & 55.75 \\
Multiflower (K6) & 3.74 & 14.71 & 22.23 & 28.27 & 46.75 \\
Tualang (K7) & 2.39 & 22.64 & 43.02 & 59.57 & 74.82 \\
\hline
\end{tabular}

Honey samples were labelled as: K1 represents acacia tree; K2 represents coconut tree; K3 represents mangrove tree; K4 represents starfruit tree; K5 represents multifruit plant; K6 represents multiflower plant; K7 represents tualang tree. Each value was shown in mean \pm standard deviation $(\mathrm{n}=3)$.

\section{$3.4 \alpha$-glucosidase inhibition assay}

$\alpha$-glucosidase inhibition ability of all honey samples was studied at the concentrations ranged from 20 to 100 $\mu \mathrm{g} / \mathrm{mL}$ (Table 4). In this assay, stingless bee honey sourced from coconut displayed the highest $\alpha$ glucosidase inhibition with $68.32 \%$ at a concentration of $100 \mu \mathrm{g} / \mathrm{mL}$. This probably related to its high phenolic and flavonoid contents as recorded in this study. 13.82 to $60.60 \%$ of $\alpha$-glucosidase inhibition was recorded among the honey samples at the concentration of $80 \mu \mathrm{g} / \mathrm{mL}$ while at the concentrations from 20 to $60 \mu \mathrm{g} / \mathrm{mL}$, all honey samples achieved less than $50 \%$ of inhibition. The least percentage inhibition for $\alpha$-glucosidase inhibition activity was observed in starfruit honey with the values from $1.08 \%$ to $20.52 \%$ along with the concentrations from 20 to $100 \mu \mathrm{g} / \mathrm{mL}$. The lowest $\mathrm{IC}_{50}(77.69 \mu \mathrm{g} / \mathrm{mL})$ was found in the honey from coconut origin whereas the honey from starfruit had the $\mathrm{IC}_{50}$ value greater than 100 $\mu \mathrm{g} / \mathrm{mL}$. Krishnasree and Mary Ukkuru (2017) showed that the stingless bee honey has a significant effect in $\alpha$ amylase and $\alpha$-glucosidase inhibition activities, however different types of bioactive compounds present in the honey from different botanical origins might influence the inhibition ability of honey (Shamsudin et al., 2019).

3.5 Correlation between bioactive compounds, $\alpha-$ amylase inhibition and $\alpha$-glucosidase inhibition

Total phenolic content was moderately correlated with $\alpha$-amylase inhibition activity and $\alpha$-glucosidase inhibition activity with the $r$ values of 0.5376 and 0.5173, respectively. Meanwhile, low positive correlations were observed between total flavonoid content, $\alpha$-amylase and $\alpha$-glucosidase inhibition activities with the $\mathrm{r}$ values of 0.1580 and 0.2327 , respectively. Both flavonoid and phenolic compounds possess a positive effect on enzyme inhibition activities, but the presence of phenolic compounds contributed more on the inhibition ability of honey. The study of Devarajan and Venugopal (2012) also stated that major phenolic compounds and flavonoid in the honey extract may increase its potential anti-diabetic effects such as in $\alpha$-amylase and $\alpha$-glucosidase inhibition activities.

\section{Conclusion}

In conclusion, phenolic and flavonoid contents of stingless bee honey samples were varied in their botanical sources and the composition of honey resulted in different $\alpha$-amylase and $\alpha$-glucosidase inhibitory abilities as there was a positive correlation between enzyme inhibition activities (i.e. $\alpha$-amylase and $\alpha$ glucosidase) and bioactive compounds. Tualang honey displayed the highest $\alpha$-amylase inhibition activity $(74.83 \%$ at $100 \mu \mathrm{g} / \mathrm{mL})$ but stingless bee honey samples from mangrove, coconut and acacia tree could potentially reduce blood glucose levels in the body, while honey from coconut origin exhibited the highest $\alpha$ -

Table 4. $\alpha$-glucosidase inhibition of honey samples

\begin{tabular}{cccccc}
\hline \multirow{2}{*}{ Samples } & \multicolumn{5}{c}{ Inhibition activity (\%) } \\
\cline { 2 - 5 } & $20 \mu \mathrm{g} / \mathrm{mL}$ & $40 \mu \mathrm{g} / \mathrm{mL}$ & $60 \mu \mathrm{g} / \mathrm{mL}$ & $80 \mu \mathrm{g} / \mathrm{mL}$ & $100 \mu \mathrm{g} / \mathrm{mL}$ \\
\hline Acacia (K1) & 1.89 & 4.87 & 12.46 & 34.46 & 38.75 \\
Coconut (K2) & 3.25 & 24.93 & 26.02 & 56.10 & 68.32 \\
Mangrove (K3) & 8.13 & 20.33 & 33.33 & 45.96 & 67.51 \\
Starfruit (K4) & 1.08 & 2.16 & 5.96 & 13.82 & 20.52 \\
Multifruit (K5) & 5.69 & 15.71 & 28.72 & 35.77 & 45.52 \\
Multiflower (K6) & 4.60 & 10.29 & 20.59 & 42.00 & 49.32 \\
Tualang (K7) & 8.13 & 33.06 & 38.75 & 60.60 & 62.60 \\
\hline
\end{tabular}

Honey samples were labelled as: K1 represents acacia tree; K2 represents coconut tree; K3 represents mangrove tree; K4 represents starfruit tree; K5 represents multifruit plant; K6 represents multiflower plant; K7 represents tualang tree. Each value was shown in mean \pm standard deviation $(\mathrm{n}=3)$. 
glucosidase inhibition activity due to its high content of phenolic and flavonoids. Therefore, stingless bee honey is suggested as a good source containing rich bioactive constituents and highly recommended to be utilized for nutraceutical and pharmaceutical applications. Further studies concerning the identification of bioactive compounds of the stingless bee honey and their verification of enzyme inhibition activity through clinical research are needed for effective management of diabetes.

\section{Acknowledgments}

The authors would like to acknowledge Universiti Tun Hussein Onn Malaysia (UTHM) for providing the facilities and financial support for this research (H 277).

\section{References}

Abd Jalil, M.A., Kasmuri, A.R. and Hadi, H. (2017). Stingless bee honey, the natural wound healer: A review. Skin Pharmacology and Physiology, 30, 6675. https://doi.org/10.1159/000458416

Abu Bakar, M.F., Sanusi, S.B., Abu Bakar, F.I., Cong, O.J. and Mian, Z. (2017). Physicochemical and antioxidant potential of raw unprocessed honey from Malaysian stingless bees. Pakistan Journal of Nutrition, 16(11), 888-894. https://doi.org/10.3923/ pjn.2017.888.894

Ahmed, S. and Othman, N.H. (2013). Review of the medicinal effects of Tualang honey and a comparison with Manuka honey. Malays Journal of Medical Science, 20(3), 6-13.

Akhir, R.A.M., Abu Bakar, M.F. and Sanusi, A.B. (2017). Antioxidant and antimicrobial activity of stingless bee bread and propolis extracts. AIP Conference Proceedings, 1891(1), 020090. https:// doi.org/10.1063/1.5005423

Alberti, K.G. and Zimmet, P.Z. (1998). Definition, diagnosis and classification of diabetes mellitus and its complications. Part 1 Diagnosis and classification of diabetes mellitus provisional report of a WHO consultation. Diabetic medicine: a journal of the British Diabetic Association, 15(7), 539-553.

Apostolidis, E., Kwon, Y.I. and Shetty, K. (2007). Inhibitory potential of herb against key enzymes linked to diabetes and hypertension. Innovative Food Science and Emerging Technology, 8(1), 46-54. https://doi.org/10.1016/j.ifset.2006.06.001

Bharti, S.K., Krishnan, S., Kumar, A. and Kumar, A. (2018). Antidiabetic phytoconstituents and their mode of action on metabolic pathways. Therapeutic Advances in Endocrinology and Metabolism, 9(3), 81-100. https://doi.org/10.1177/2042018818755019
Campone, L., Piccinelli, A.L., Pagano, L., Carabetta, S., Sanzo, R., Russo, M. and Rastrelli, L. (2014). Determination of phenolic compounds in honey using dispersive liquid-liquid microextraction. Chromatography Analysis, 1334, 9-15. https:// doi.org/10.1016/j.chroma.2014.01.081

Cho, N.H., Karuranga, S., Huang, Y., Rocha, D.F.J.D., Ohlrogge, A.W. and Malanda, B. (2018). IDF diabetes atlas: Global estimates of diabetes prevalence for 2017 and projections for 2045. Diabetes Research and Clinical Practise, 138, 271281. https://doi.org/10.1016/j.diabres.2018.02.023

Devarajan, S. and Venugopal, S. (2012). Antioxidant and $\alpha$-amylase inhibition activities of phenolic compounds in the extracts of Indian honey. Chinese Journal of Natural Medicines, 10(4), 255-259. https://doi.org/10.1016/S1875-5364(12)60051-X

Erejuwa, O.O., Sulaiman, S.A. and Wahab, M.S. (2011). Oligosaccharides might contribute to the antidiabetic effect of honey: A review of the literature. Molecules, 17(1), 248-266. https://doi.org/10.3390/ molecules 17010248

Eteraf-Oskouei, T. and Najafi, M. (2013). Traditional and modern uses of natural honey in human diseases: A review. Iranian Journal of Basic Medical Sciences, 16(6), 731-742.

Hoffman, R. and Gerber, M. (2015). Food processing and the Mediterranean diet. Nutrients, 7(9), 79257964. https://doi.org/10.3390/nu7095371

Inoue, R., Suzuki, N. and Nagashima, T. (2007). $\alpha-$ amylase from persimmon honey: Purification and characterization. Food Properties, 19(7), 512-521.

Islam, M.R., Pervin, T., Hossain, H., Saha, B. and Hossain, S.J. (2017). Physicochemical and antioxidant properties of honeys. Journal of Preventive Nutrition and Food Science, 22(4), 335344. https://doi.org/10.3746/pnf.2017.22.4.335

Istasse, T., Jacquet, N., Berchem, T., Haubruge, T., Nguyen, B.K. and Richel, A. (2016). Extraction of honey polyphenols: Method development and evidence of cis isomerization. Analytical Chemistry Insights, 11, 49-57. https://doi.org/10.4137/ ACI.S39739

Kaskoniene, V. and Venskutonis, P.R. (2010). Floral markers in honey of various botanical and geographic origins: A review. Comprehensive Reviews in Food Science and Food Safety, 9(6), 620 -634 .

4337.2010.00130.x https://doi.org/10.1111/j.1541-

Krishnasree, V. and Mary Ukkuru, P. (2017). In vitro anti-diabetic activity and glycemic index of bee honeys. Indian Journal of Traditional Knowledge, 
16(1), 134-140.

Lim, D.C.C., Abu Bakar, M.F. and Majid, M. (2019).

Nutritional composition of stingless bee honey from different botanical origins. IOP Conference Series: Earth and Environmental Science, 269, 012025. https://doi.org/10.1088/1755-1315/269/1/012025

Majid, M., Abu Bakar, M.F., Mian, Z., Esa, F. and Yeow, Y.K. (2019). Variations of physicochemical properties of stingless bee honey from different botanical origin in state of Johor, Malaysia. IOP Conference Series: Earth and Environmental Science, 269, 012028.https://doi.org/10.1088/17551315/269/1/012028

Mohd Rafie, A.Z., Syahir, A., Wan Ahmad, W.A.N., Mustafa, M.Z. and Mariatulqabtiah, A.R. (2018). Supplementation of stingless bee honey from Heterotrigona itama improves antiobesity parameters in high-fat diet induced obese rat model. Evidence-Based Complementary and Alternative Medicine, 2018, 6371582. https:// doi.org/10.1155/2018/6371582

Rahmawati, O., Pratami, D.K. and Raffiudin, R. (2019). Alpha-glucosidase inhibitory activity of stingless bee honey from Tetragonula biroi and Tetragonula laeviceps. AIP Conference Proceedings, 2092(1), 030001. https://doi.org/10.1063/1.5096705

Rutebemberwa, E., Lubega, M., Katureebe, S.K., Oundo, A., Kiweewa, F. and Mukanga, D. (2013). Use of traditional medicine for the treatment of diabetes in Eastern Uganda: a qualitative exploration of reasons for choice. BioMed Central, 13, 92-103. https:// doi.org/10.1186/1472-698X-13-1

Shamsudin, S., Selamat, J., Sanny, M., Shamsul Bahari A.R., Jambari, N.N. and Khatib, A. (2019). A comparative characterization of physicochemical and antioxidants properties of processed Heterotrigona itama honey from different origins. Molecules, 24 (21), $\quad 1-20 . \quad$ https://doi.org/10.3390/ molecules 24213898

Shaw, J.E., Sicree, R.A. and Zimmet, P.Z. (2010). Global estimates of the prevalence of diabetes for 2010 and 2030. Diabetes Research and Clinical Practice, 87(1), 4-14. https://doi.org/10.1016/ j.diabres.2009.10.007

Yap, P., Bakar, M.F.A., Lim, H. and Carrier, D. (2015). Antibacterial activity of polyphenol-rich extract of selected wild honey collected in Sabah, Malaysia. Journal of Apicultural Research, 54(3), 163-172. https://doi.org/10.1080/00218839.2016.1151633 